\title{
Rehabilitation Projects of the Areas of the Decommissioned Barraks in Milan, 2014
}

\author{
Raffaella Neri
}

\begin{abstract}
Projects and studies were born from a research and a workshop promoted by the School of Architettura Civile and continued through master thesis and a Convention with the Ministry of Defense. The paper deals with the role that these areas can play in the transformation of peripheral sites through the settlement of new activities and collective places, parks and residential activities, as well as the possibility of recovering existing structures. The chapter includes a selection of projects.
\end{abstract}

Keywords Barraks $\cdot$ Decommissioned areas $\cdot$ Urban design $\cdot$ Urban composition

Today, the main transformations of historically established systems mostly happen when large areas are decommissioned and become newly available to the city for redevelopment. After the decommissioning of large industrial sites that began in the 1970s and the long process to redevelop them for new programs, other large areas are now becoming available in Milan and in several other cities as the result of structural changes in production, transportation, institutional. The guidelines of urban and territorial plans reflect such changes in ways that generally refer to particular issues and programs: today, the main strategic areas, in Milan and in other Italian and European cities, are rail-road yards and military areas, either already decommissioned or in the process of becoming so. As such, they are the object of a special focus by the master plans that are expected to indicate their future transformation. When important programs that usually occupy large sections of the city's core get relocated, they usually leave behind valuable buildings or architectural complexes. In any case, they are often particularly relevant in terms of location and size as they form large enclaves within the established built fabric between the city core and its suburbs. As large, enclosed areas, set apart and inaccessible, they are still intact and thus can be repurposed for a totally different and surprising new life. Their availability represents an important resource that can potentially redefine, subvert and guide the future life

R. Neri ( $\bowtie)$

Architecture, Built Environment and Construction Engineering-ABC Department, Politecnico di Milano, Milan, Italy

e-mail: raffaella.neri@polimi.it 
of the neighboring city sections, with an influence that reaches out to farther areas they may be reconnected to.

In 2014, the School of Architettura Civile promoted a workshop about either decommissioned or soon to be decommissioned barracks - considered as strategic areas by the new territorial zoning plan - that was based on the results of an ongoing research started in 2012. This research has revealed extended, complex and rich, due to the multiplicity of issues it tackles, such as the impact of the military settlements' diverse purposes and layouts on the construction of the city; the different and multiple reasons of their location; the settlement and typological features of the barracks as large complexes that incorporate several buildings and large open areas, as reflected by an extended and established literature; how their sites and buildings reflect military life and organization; their building practices and decoration forms; the complex and unexplored connections with other similar situations in Italy and abroad, and so on. While these settlements have general and recurring features, their urban condition is so particular and specific that they are, at the same time, deeply related to the city and its history.

Due to their programs, these are almost invariably very large developments that acquire specific and different features when they expand. During the course of history their large enclosed areas have been relocated within the city for different reasons, and left important traces of their presence in the sites, buildings and conditions they generate all around. These are settlements that influence urban design by establishing or preventing relations between city sections that remain in place even after their decommissioning.

Eleven design groups that include professors, researchers, students and graduate students, and the contribution of several others, have worked on the sites of five decommissioned, or about to be decommissioned, barracks, originally indicated by the territorial zoning plan as areas for urban transformation. These were the barracks of the Milizie district, involved in the long discussion about the relocation of the Brera Academy, the large unbuilt site of the Parade Ground in Baggio a small section of which is occupied by warehouses, the Montello barracks in via Caracciolo, the Mameli barracks in viale Suzzani and finally, the Mercanti barracks in via Rubattino in the Lambrate district.

The projects always consider the areas and the built heritage that will be soon available for their potential in terms of urban transformation and redevelopment, of enhancement of the contexts and their buildings, with the goal of redefining the sites that will become newly available to the city by establishing collective facilities of urban interest, public institutions, open areas and parks, new facilities and community centers, buildings for social activities and programs, by calling for the redevelopment and construction of buildings for special, temporary, protected, collective, emergency housing, and so on. These large strategic areas can guide the transformations of the city and become its new centers, new landmarks that integrate and consolidate the city's collective sites, as public places of urban and territorial relevance that can rarely be found in the city's suburbs. 


\section{A Regeneration Project for the Military Area in the Baggio District of Milan: A Park and Square for West Milan}

Milan has a long history of moving its "piazza d'armi" (military camp and stronghold), but this never-ending saga of "fated moves" (F. Reggiori) is about to be resolved once and for all with the removal of the city's last military camp on via delle Forze Armate. This affair has played a fundamental role in the history of Milan and its architecture, and is also important if one wishes to have a better understanding of the city. The main character in this story is a masterpiece of Milanese Renaissance architecture: the large porticoed enclosure of the Lazzaretto (a lazaretto, i.e. isolation hospital). The site, therefore, poses various complexities which the project resolves by using the architecture of the Lazzaretto as its central point of reference. The main aim of the project is to give shape to the themes posed by the new phase of the area's transformation while respecting its identity and also enabling the site to use the invaluable expanses of space that are an intrinsic part of its character and have been lost to us for so long. This is the key to expressing a new quieter and more cloistral centricity, which is required for an archipelago of separate units that are otherwise unable to express any civilized character (Fig. 1).

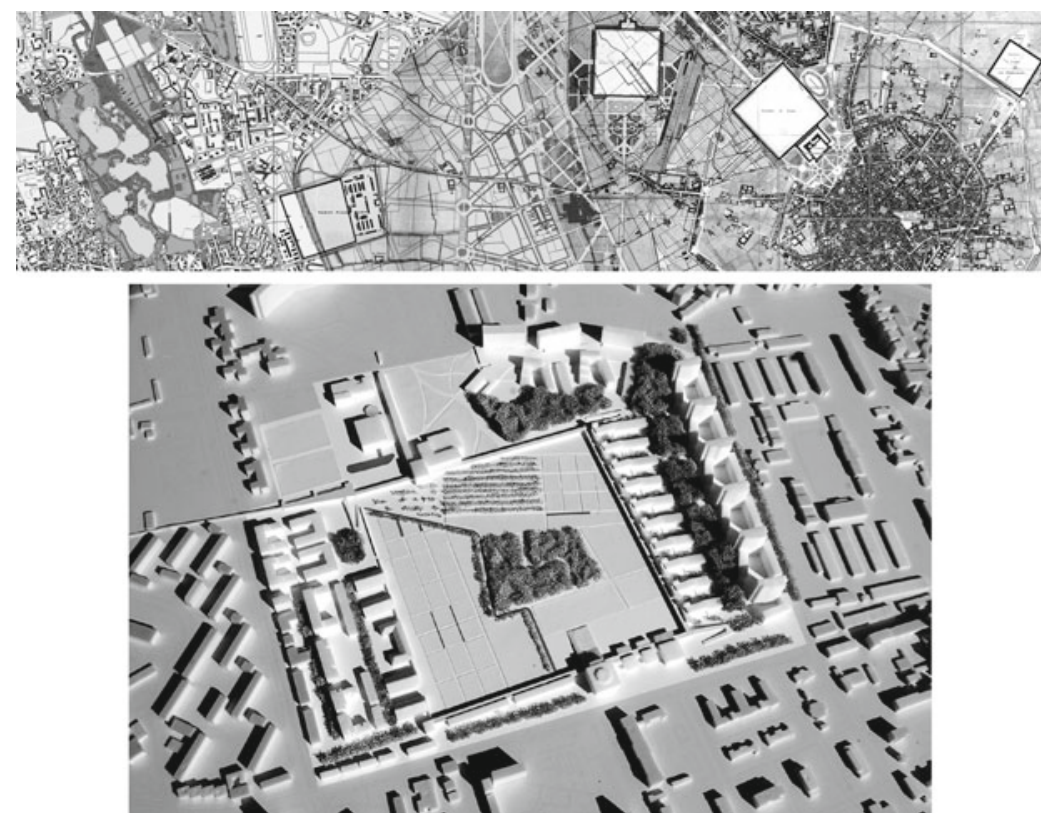

Fig. 1 History of the "Piazze d'armi" in Milan; perspective view of the maquette. Design group: M. Prusicki, with P. Cofano, E. Colonna, G. Frassine, M. Cristina Loi, F. Pocaterra, A. Schiavo, A. Drufuca (Mobilità), A. Ferrari (Verde) and C. Bianchi, C. Candia, A. Cova, Q. Lu, E. Solbiati, M. Sundovska, Pupak Tahereh B., G. Tacchini (Ph.D. students) and students of the Scuola di Architettura Civile 


\section{Asylum. City-Refuge. The Milan Barracks: Replacement, Conservation, Adaptation or Physiological Transformation?}

The project takes on board the task of requalifying the civil life of fairly heterogeneous communities, the current and real representation of the other "total institutions" (the prison system, those of education and professional training, health, social security, labor organisations, et cetera) in their direct relations with social society, according to two strategies to be considered interlinked:

- the first for ordinary administration, with the building of a Cite de Refuge aimed at reorganizing activities to curb the hardships and privations of outcasts, the "wretched of the earth" (from the title of Frantz Fanon's 1961 essay);

- the second for extraordinary management, with the establishment of a "Center for Strategic Coordination of the Environment."

In short, we are not talking about "liberating"—emptying ad excludendummilitary zones and barracks, but instead about making use of them through compatible activities, reconverting the military arrangement into an internal front-i.e. to the problems of civil society - to redeem through typological devices-Asylums - the segregation regime of "total institutions." Even if the extant building types can be adapted for use as temporary residences, nonetheless the need emerges to conceive functions of social integration, such as training courses at various levels along with social activities (Fig. 2).

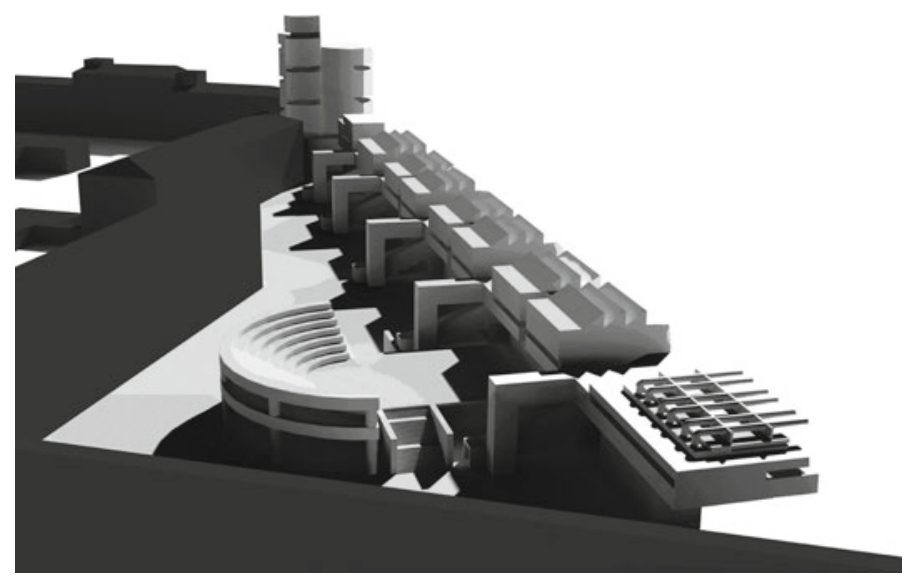

Fig. 2 Perspective view of the Baggio decommissioned area. Design group: R. Canella, M. Dezzi Bardeschi, G. Luca Ferreri, L. Monica with L. Bergamaschi, M. Bordin, A. Brusetti, M. Canesi, G. Cattani, S. Cusatelli, G. Fiorese, P. Galbiati, V. Garatti and students of the Scuola di Architettura Civile 


\section{A Sports Park in Baggio}

The project reflects the guidelines of Milan's territorial zoning plan about the activities and quantities that could be developed in the area. The extension of the area and possibility to accommodate new urban collective activities are the conditions that can project the areas as new city centers, and public, open, green locations with common activities and public institutions.

The project proposes it as the site for new urban-scale sports facilities-a new water sports complex and a sports palace fronting on the central green park that, along with its public buildings, acts as the main element of the new development.

The remarkable housing volume planned by the territorial zoning plan is concentrated in few large buildings located in the park and integrated with the necessary district facilities: the housing is laid out to provide a satisfying connection between the buildings and the central free area (Fig. 3).

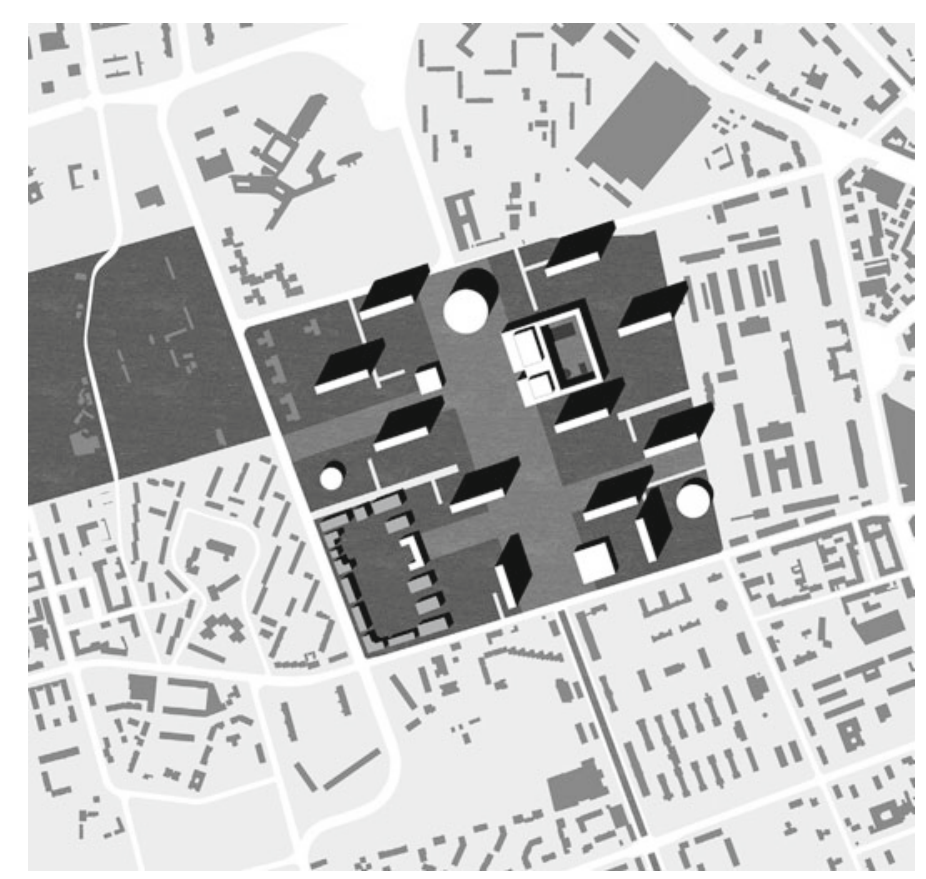

Fig. 3 Masterplan for the Baggio decommissioned area. Design group: R. Neri, T. Monestiroli, I. Boniello with: C. Campanella, E. Garavaglia, G. Guarisco, M. Passerella, F. Zangheri and students of the Scuola di Architettura Civile 


\section{Montello Barracks, Between via Caracciolo, via Arimondi, via Bertolini, via Amari. Adaptive Reuse for Prison Decongestion Structures, Public Housing and Collective Services}

The Montello Barracks, former "Caserma di Cavalleria al Rondò della Cagnola" (Cavalry Barracks of Cagnola Circus), was built between 1910 and 1913 on the boundary of Corso Sempione, historic axis of Milan's expansion toward the northwest, in a segment between the current Piazza Firenze, via Caracciolo, via Arimondi, via Bartolini and via Amari. The ensemble's typology, pavilions type, was recurrent in the later nineteenth century, recommended by the reference handbooks to several large urban facilities (barracks but also hospitals, hospices, nursing homes, markets, expo, etc.). The project aims to answer to several current urban and social emergencies and requirements. In detail, there are provided: structures for the reduction of the prison overcrowding, by means of a housing unit for the semi-detention treatments placed in a new construction toward via Bartolini; some studios and workspaces for training and apprenticeship, obtained reusing the stables and the riding-school building near to via Arimondi; also, public housing and accommodations for students, immigrants, elderly and vulnerable population obtained recovering a large part of the building in via Caracciolo. In the central part of lot, there will be a new compound building, that has an out-of-alignment position against the original complex. This will host an auditorium and other cultural and associative spaces, as well as sports equipment and a public swimming, with adjoining cabins and utilities; while on the short side toward via Amari, a linear building hosts a cafeteria, a library and study rooms (Fig. 4).

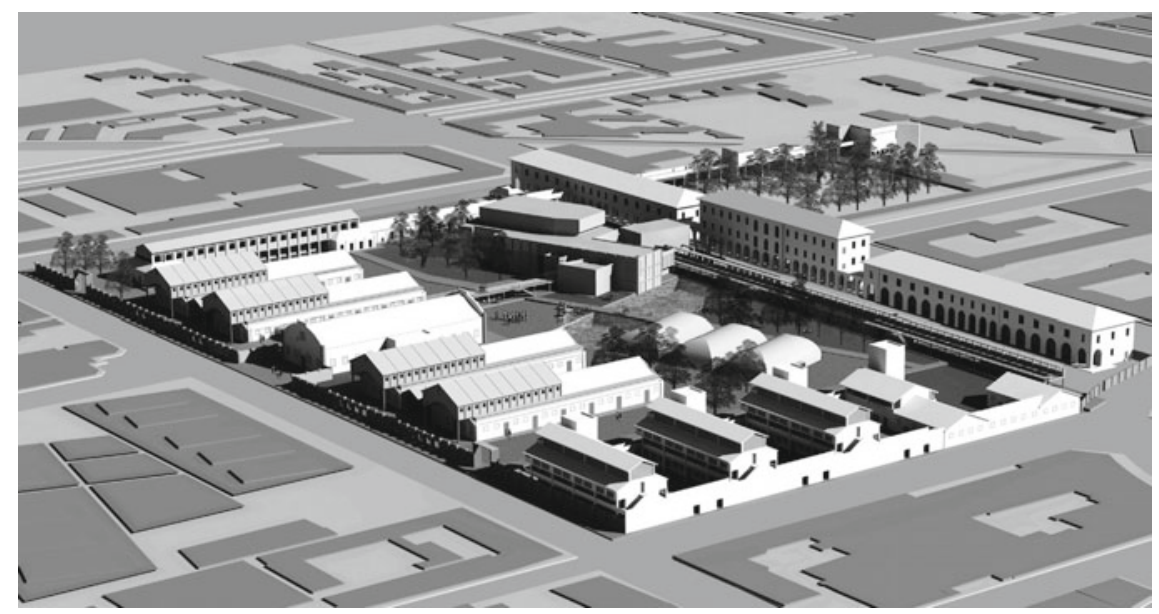

Fig. 4 Axonometric view from northeast of the Montello barraks to prison decongestion structures, public houses and collective services. Design group: E. Bordogna, G. Canella, E. Manganaro with: T. Brighenti, F. Costantino, L. Locatelli and students of the Scuola di Architettura Civile 


\section{A Project for Brera's Academy}

The projects deal with the functional re-zoning of the so-called Quartiere delle Milizie, a urban complex composed by several barracks, such as XXIV Maggio's, Magenta's and Carroccio's. Quartiere delle Milizie is located at the west of Parco Sempione, between Giardino Valentino Bompiani and Parco Guido Vergani, in an area that developed in the late eighteenth century. The new urban layout defines a square which, affected by the dramatic nature of the surrounding context, fragments its edges and reveals connections with the existing civic pattern. The project, characterized by variances and cross-references, maintains unaltered the architectural character of XXIV Maggio and Carroccio's barracks. Moreover, it replaces Magenta's barracks with a large building which hosts the board of education of Brera's Academy and defines a new public space where different multi-functional buildings appear (Fig. 5).

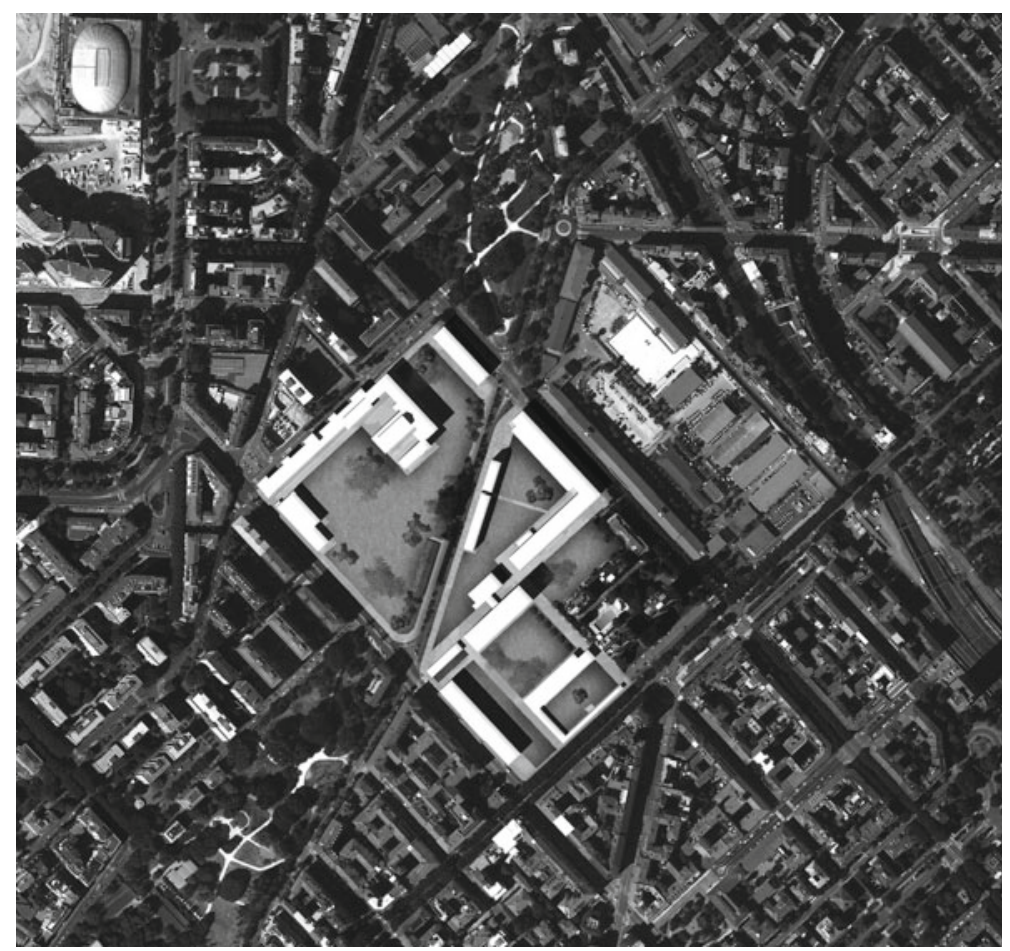

Fig. 5 Masterplan for the "quartiere delle Milizie" area. Design group: R. Bonicalzi, F. Bruno, F. Belloni, E. Miele, V. Petrini with: A. Faniuolo, L. Forti, V. Lattante, L. Spinelli, D. Vallariello and students of the Scuola di Architettura Civile 


\section{A New Center for Brera: Barrack "XXIV Maggio-Magenta-Carroccio"}

The projects start from the assumption of partial or complete displacement of the Brera Academy, reusing the listed buildings of the district "XXIV Maggio-Magenta-Carroccio," taken as ordering elements of the new system of buildings, hinged on the barracks of via Mascheroni.

This barrack is reconstructed according to the design of the late nineteenth century and is divided into three parts: the existing linear building of Via Mascheroni, the building of the "Ex Leva" barracks and the internal central one, originally U-shaped, of which remains only the right-wing. This fragment is freed from the one-story adjunct, which connects it to the slim building along Via Pagano ("Carroccio" barracks), and is reconstructed as it was around the central courtyard. The new rebuilt building completes the existing one, taking from this its volume size, its height, the order of the openings and interrupting itself only at the transverse passage, which is accessible from the entrance gate on the Via Pagano (Fig. 6).

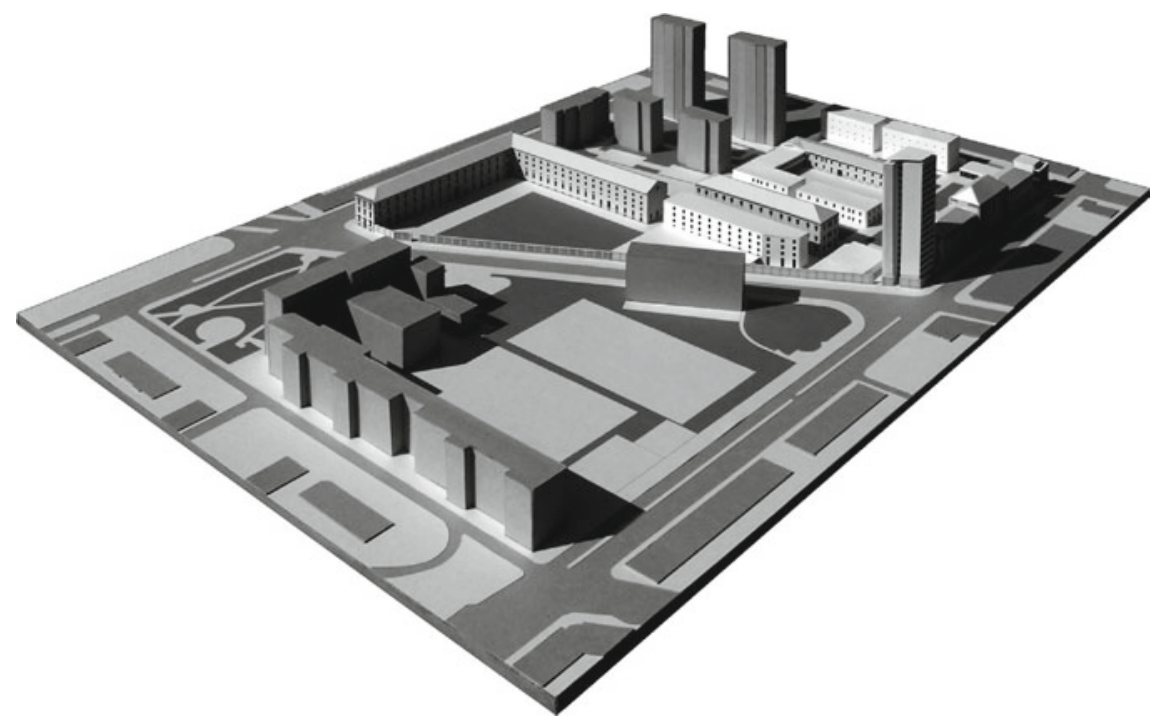

Fig. 6 View of the project for the "quartiere delle Milizie" area. Design group: M. Caja, P. Iarossi, N. Lombardini with M. Foglia, S. Zaroulas nd students of the Scuola di Architettura Civile 


\section{Former Military Barracks: From Isolated Fortress to Place of Integration}

The architecture of the barracks introduces in the city the typical features of military settlements: demarcation and separation from the urban body, introversion of the system of activities, plurality of typological structure. The presence of spatial differences according to several functional diagrams assigns barracks' features to the ones which are distinctive of the city, as it is condensed within the confined horizon of a separate community: that is to say a real "citadel."

The divestment military areas and properties represent a potential system of extraordinary devices able to cope with major social emergencies according to a logic of integrated mobilization of resources. For each of the four former barracks has been identified a priority task capable of positive synergies with other activities and functional systems: for prison decongestion (achieved through alternatives measures to detention): Montello Barracks; for the assistance to the immigrant population: Military Citadel of Baggio; for housing and services for elderly population and students: Mameli and Mercanti Barracks; for affordable housing and utilities: Military Citadel of Baggio (Fig. 7).

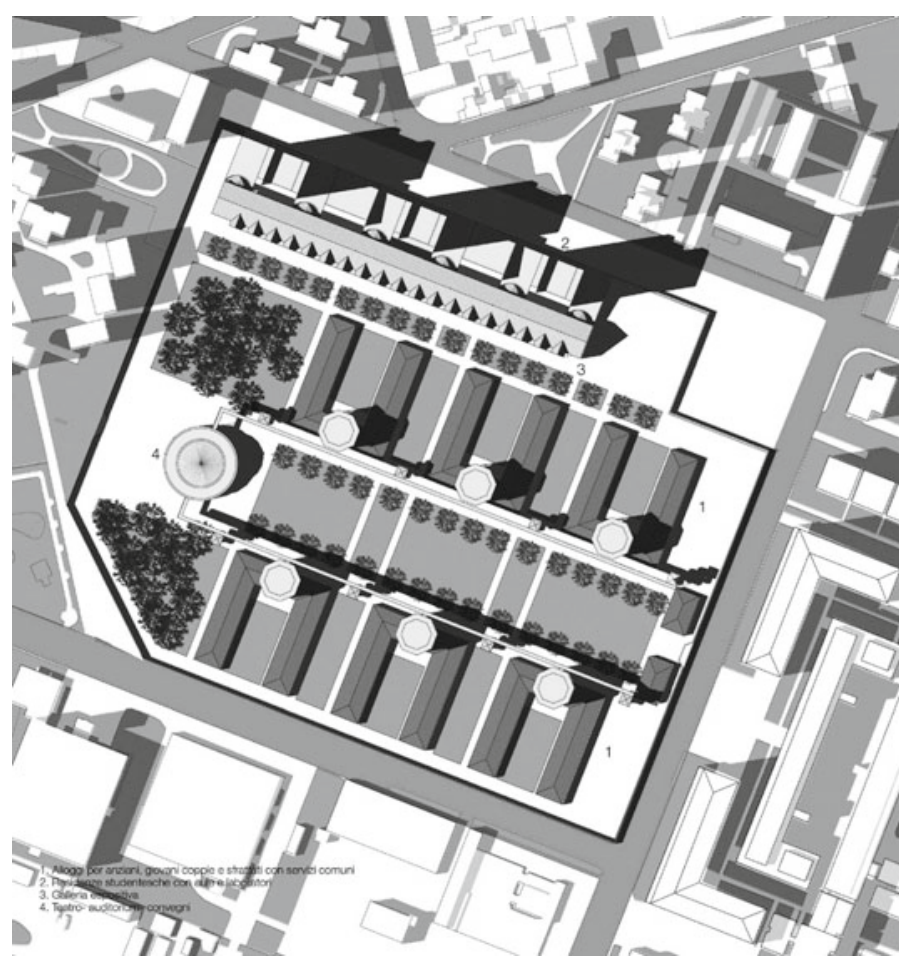

Fig. 7 Masterplan for the "quartiere delle Milizie" area. Design group: P. Bonaretti, M. Biagi, C. Pavesi and students of the Scuola di Architettura Civil 


\section{A Park for the Temporary Housing in the Mameli Barracks}

The Mameli barracks is a wide enclosure over $300 \mathrm{~m}$ long; a remarkable building volume is planned in the area as the site for housing and collective facilities. The superintendency intends to preserve most buildings all while allowing for their partial enlargement and adaptation.

The project develops the large central area as a new collective park for the neighborhood, a green open area that extends to create smaller gardens between the buildings as a sort of urban outpost of the northern Park.

Given the layout of the barracks, its proximity with the Bicocca University campus and the presence of several major hospital facilities nearby (Niguarda, CTO, Galeazzi, Bassini), it seems advisable to develop the existing buildings and the new developments as the system of temporary and social housing that the city currently lacks: student housing, hospital-related accommodation, small temporary units, some social housing, along with public and collective facilities to serve the new development and integrate the other developments of the city all around it.

Two buildings for hotel facilities are aligned with the central park; their layout creates a two-level square that defines the system's hub, distributes to the development's open space, the facilities in the hotel buildings and the underground squares, and provides access to the housing. A third tower that becomes the area's boundary to the densely built area to the north accommodates small-sized housing units and social housing (Fig. 8).

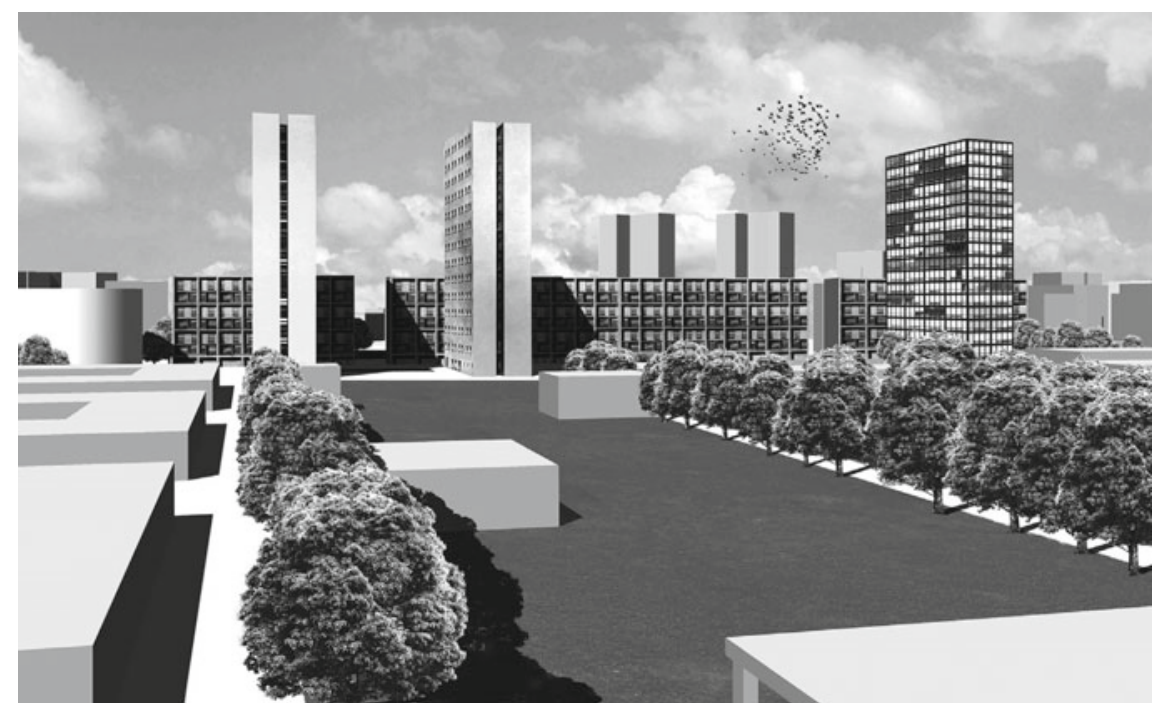

Fig. 8 Masterplan for the Mameli decommissioned area. Design group: R. Neri, T. Monestiroli, I. Boniello with: C. Campanella, E. Garavaglia, G. Guarisco, M. Passerella, F. Zangheri and students of the Scuola di Architettura Civile 
Open Access This chapter is licensed under the terms of the Creative Commons Attribution 4.0 International License (http://creativecommons.org/licenses/by/4.0/), which permits use, sharing, adaptation, distribution and reproduction in any medium or format, as long as you give appropriate credit to the original author(s) and the source, provide a link to the Creative Commons license and indicate if changes were made.

The images or other third party material in this chapter are included in the chapter's Creative Commons license, unless indicated otherwise in a credit line to the material. If material is not included in the chapter's Creative Commons license and your intended use is not permitted by statutory regulation or exceeds the permitted use, you will need to obtain permission directly from the copyright holder.

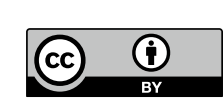

